\title{
İçme Sütü Üretiminde ESL (Extended Shelf Life) Teknolojisinin Kullanımı
}

\author{
Naciye ÜNVER ${ }^{1 *}$, Şerafettin ÇELIK ${ }^{1}$ \\ ${ }^{1}$ Harran Üniversitesi Ziraat Fakültesi Gıda Mühendisliği Bölümü, Şanlıurfa \\ "Sorumlu yazar: unver.naciye@harran.edu.tr
}

Öz

Günümüzde içme sütü üretim teknolojisinde, en çok bilinen ve uygulanan ısıl işlemler pastörizasyon ve UHT teknolojisidir. Pastörizasyonla kısa ömürlü ancak taze bir ürün elde edilirken; UHT ile uzun ömürlü ancak duyusal olarak beğeni düzeyi daha düşük bir ürün elde edilmektedir. Bu bağlamda ESL teknolojisi, pastörize süte göre daha uzun ömürlü ve duyusal olarak tüketiciye daha cazip bir ürün sunmak amacıyla geliştirilmiş yeni bir yöntemdir. Bu yöntem; mikrofiltrasyon, baktofügasyon, vurgulu elektriksel alan, yüksek basınç uygulaması gibi işlemleri de içerisinde bulundurabilmektedir. Bu yöntem ile hijyenik şartlarda paketlenen süt, buzdolabı sıcaklığında muhafaza edildiği sürece pastörize süte oranla daha uzun raf ömrüne sahip olmaktadır. Mikrobiyolojik riskin azaltılması ve raf ömrünün uzatılması açısından bu teknik, düşük yoğunluklu ısıl işlemle birlikte kullanılmalıdır. Düşük yoğunluklu ısıl işlem uygulaması; protein denatürasyonu, vitamin parçalanması, Maillard reaksiyonu gibi istenmeyen oluşumların düzeyini de azaltmaktadır. Bu teknoloji ile 45-60 güne kadar muhafaza edilebilen ve duyusal olarak pastörize süte daha yakın bir ürün elde edilmektedir. Bu çalışmada amaç, içme sütü üretiminde ESL teknolojisinin uygulanabilirliğini incelemek ve bu teknolojiyi diğer ısıl işlemlere göre ve kendi içinde değerlendirmektir.

Anahtar Kelimeler: Baktofügasyon, ESL süt, Mikrofiltrasyon, Pastörizasyon, UHT

\section{Application of ESL (Extended Shelf Life) Technology in Drinking Milk Production}

\begin{abstract}
Nowadays pasteurization and UHT are the best known and most commonly used technologies in milk production. While products which have shorter shelf life and fresh taste are obtained by using pasteurization, products which have longer shelf life but less desirable taste are obtained by UHT technology. ESL technology is a new method which was developed to obtain a longer shelf life product than pasteurized milk and better sensory quality product than UHT milk. ESL milk includes technologies such as microfiltration, bactofugation, pulsed electric fields, high pressure processing. In this process milk packaged under hygienic conditions has a longer shelf life than pasteurized milk as long as it has stored under refrigerated conditions. This technique should be used with low intensity heat treatment in order to minimize microbial risk and prolong the shelf life. This gentle heat treatment reduces the undesired reactions such as protein denaturation, vitamin degradation and Maillard reactions. Product which has a shelf life between 45-60 days and similar sensory characteristics with pasteurized milk is obtained owing to this technology. The objective of the study is to examine applicability of ESL technology in the field of milk production, evaluate and compare with traditionally heat treatments and itself.
\end{abstract}

Key Words: Bactofugation, ESL milk, Microfiltration, Pasteurization, UHT

Giriş

Üretimden tüketiciye ulaşıncaya kadar gıdalar, çevresel kaynaklı veya gıdanın kendi kimyasal ve mikrobiyolojik yapısından kaynaklı pek çok değişime uğramaktadırlar. 
$\mathrm{Bu}$ değişimleri önleyici veya yavaşlatıcı geleneksel muhafaza yöntemleri; başta ısıl işlemler olmak üzere, düşük sıcaklıkta muhafaza, kurutma, fermantasyon, tuzlama, şeker ilavesi olarak sıralanabilir. Bu işlemlerin yoğunluğu, gıdanın duyusal ve besinsel değerini önemli düzeyde etkilemektedir. $\mathrm{Bu}$ sebeple bu işlemlerin hem gıda güvenliğini sağlayacak düzeyde hem de gıdanın besin değerine ve duyusal özelliklerine zarar vermeyecek düzeyde kontrollü bir biçimde gerçekleştirilmesi önemli bir husustur. Gıda muhafazasında bu iki faktör arasındaki dengeyi sağlamak için geleneksel yöntemlere alternatif olarak geliştirilen yeni yöntemlere başvurulmaktadır. Bu yeni yöntemler, geleneksel yöntemlerin son üründe oluşturduğu olumsuzlukları gidermeyi veya bunları en aza indirgemeyi amaçlamaktadır. $\mathrm{Bu}$ yöntemler tek başlarına veya farklı yöntemlerle kombine edilerek kullanılabilmektedirler. Bu bağlamda ESL (Extended Shelf Life) süt teknolojisi, uzun süredir yaygın olarak kullanılan pastörize ve UHT (Ultra High Temperature-Ultra Yüksek Sıcaklık Uygulaması) süt teknolojilerinin eksikliklerini gidererek tüketiciye daha cazip bir ürün sunmak amacıyla geliştirilmiş yeni bir yöntemdir.

UHT süt teknolojisi, pastörize süte göre daha uzun raf ömrüne sahip bir ürün geliştirmek amacıyla ortaya çıkmıştır. Ancak duyusal olarak değerlendirildiğinde UHT sütte algılanan pişmiş tat, UHT sütün pastörize süte göre beğeni düzeyini düşürmektedir (Rysstad ve Kolstad, 2006; Mayer ve ark., 2010). Ayrıca ısıl işlem yoğunluğu arttıkça besin değerinde de azalmaların meydana geldiği bilinmektedir (Gündoğdu ve ark., 2012). Bu faktörler dikkate alındığında tüketicinin hem uzun süre dayanıklılığını koruyabilen hem de duyusal ve besleyici açıdan kaliteli bir ürün talebi, endüstriyi yeni teknolojiler geliştirmeye yöneltmiştir. ESL süt teknolojisi de bu amaçla oluşturulan ve yaklaşık 60 yıldır süt ve süt ürünlerinde kullanılan bir yöntemdir. Kısaca tanımlamak gerekirse ESL süt; mikrofiltrasyon (MF), baktofügasyon, vurgulu elektriksel alan (VEA), yüksek hidrostatik basınç uygulaması (YHB) gibi işlemleri de içerisinde bulunduran, son derece hijyenik şartlarda (genellikle yüksek verimlilikteki filtre edilmiş partiküler hava ile temizlenmiş paketler kullanılarak) paketlenen ve buzdolabı sıcaklığında muhafaza edildiği sürece pastörize süte göre daha uzun raf ömrüne sahip olan bir üründür (Fernández García ve Rodríguez, 2014; Henyon, 1999).

Sıcaklık ve zaman, ısıl işlemin yoğunluğunu belirleyen en önemli iki parametredir. Genellikle süt endüstrisinde bu parametreler pastörizasyon için 72$75^{\circ} \mathrm{C} / 15-30$ sn iken, UHT için minimum $135^{\circ} \mathrm{C} / 1-2$ sn şeklindedir. ESL süt teknolojisi ise bu 2 parametre yönünden değerlendirildiğinde UHT'ye göre daha ılımlı, pastörizasyona göre ise biraz daha yoğun bir uygulamadır. Bu uygulamanın UHT'ye göre daha düşük sıcaklıklarda mikrobiyolojik açıdan güvenli bir ürün oluşturması mikrofiltrasyon gibi yeni geliştirilen yöntemlere dayanmaktadır. Yeni geliştirilen bu yöntemlerle öncelikle sütteki mikroorganizma yükü azaltılmakta ve ardından uygulanan ısıl işlemle güvenilir bir ürün elde edilmektedir. Isıl işlem yoğunluğuna ve depolama koşullarına bağlı olarak ürünlerin raf ömürleri de değişmektedir. Örneğin; pastörize sütler $+6^{\circ} \mathrm{C}^{\prime}$ nin altındaki sıcaklıklarda 5-8 gün muhafaza edilebilirken, UHT sütler oda sıcaklığında 3-6 ay muhafaza edilebilirler. Yapılan çalışmalara göre ESL süt ise $+4^{\circ} \mathrm{C}^{\prime}$ de 3 haftaya kadar muhafaza edilebilmektedir (Lorenzen ve ark., 2011). 
Genellikle ısıl işlem yoğunluğu arttıkça vitamin degradasyonu, protein denatürasyonu, Maillard reaksiyonu gibi istenmeyen oluşumlar söz konusu olabilmektedir. UHT uygulaması, kısa süreli yüksek sıcaklık [KSYS (HTST: High Temperature Short Time)] pastörizasyon uygulamasına göre daha yoğun bir uygulama olduğu için sütün vitamin içeriğinde daha çok kayba sebep olmaktadır. Özellikle $B_{6}, B_{12}$ gibi sıcaklığa hassas suda çözünen vitaminler, yüksek ısıl işlem normundan daha çok etkilenmektedir. Ayrıca ısıl işlemin, sütün antioksidatif özelliklerini arttırdığı ve sütte pişmiş tat oluşmasına sebep olduğu belirtilmektedir. Yapılan çalışmalar, protein denatürasyonunun başladığı $70-80^{\circ} \mathrm{C}$ sıcaklık derecesinde en yüksek seviyeye ulaşan ve sıcaklık artışıla paralel olarak miktar bakımından artış gösteren reaktif SH (tiyol) gruplarının, lipid peroksidasyonunu önleyerek sütün antioksidatif özelliklerini arttırdığını belirtmektedir (Velioğlu Öğünç ve Yalçın, 2011). Denatürasyon, proteinlerin 3 boyutlu yapısında değişime sebep olurken sütün besin değerini etkilememektedir. Ancak yüksek sıcaklıklarda bazı aminoasitlerin yapısında oluşan hasar sütün besin değeri değiştirebilmektedir. İndirgen şekerler (laktoz) ile aminoasitler arasında gerçekleşen Maillard reaksiyonu ise lisin ve arginin gibi temel aminoasitlerin kaybının yanı sıra renk, tat ve aromada değişikliğe sebep olan bir reaksiyondur (Raynal-Ljutovac ve ark., 2007). Sıcaklığın $180^{\circ} \mathrm{C}$ olduğu ve su aktivitesinin 0.6-0.7 olduğu değerde optimum düzeyde gerçekleşen bu reaksiyon, ısıl işlem yoğunluğundaki artışa bağlı olarak hız kazanmakta ve sütün koku ve renginde olumsuzluklar yaratmaktadır. Bu sebepler göz önünde bulundurulduğunda UHT teknolojisine göre daha ılımlı bir ısıl işlem olan ESL süt teknolojisinin önemi ortaya çıkmaktadır.

Isıl işlem normunu belirleyen en önemli faktör mikroorganizmalardır. Schmidt ve ark. (2012)'e göre işlenmiş sütte proteinaz, lipaz ve fosfolipaz aktivitesine bağlı olarak duyusal bozukluklar oluşturan en önemli mikroorganizma Bacillus cereus sporlarıdır. Bazı Bacillus cereus spor oluşturabilen suşlarının buzdolabı sıcaklıklarında bile çoğalıp gelişebildikleri bilinmektedir. Toprak kaynaklı olan Bacillus cereus süte genelde sağım sırasında bulaşır ve bu mikroorganizma hidrofilik özelliklerinden dolayı cam, plastik gibi çeşitli ambalaj materyallerinin yüzeyinde biyofilm oluşturabilir (Kalkan ve Halkman, 2006). Bunun dışında dolum ve paketleme materyallerinden bulaşabilen Pseudomonas ve Aeromonas cinsi ve Enterobacteriacae familyasına ait bazı gram negatif psikrotrofik mikroorganizmalar da sütte sorunlar oluşturabilmektedir (Rysstad ve Kolstad, 2006). ESL teknolojisinde kullanılan geleneksel mikrofiltrasyon yöntemiyle ile bakteriyel spor formunda 3 log düzeyinde azalma sağlanırken, yeni çok katmanlı membran teknolojileriyle $4-5$ log düzeyinde azalma sağlanmaktadır (Hoffmann ve ark., 2006). Ancak mikrofiltrasyonda kullanılan gözenek büyüklüğü $(0.8-1.4 \mathrm{~mm})$ bazı bakterilerin membrandan geçişini önleyemediği için filtre edilen süt, ardından Isıl işleme tabi tutulmakta ve bakteriyel spor formunda 8 log düzeyinde bir azalma sağlanmaktadır (Rysstad ve Kolstad, 2006).

Termal proseslerin sütteki etkisini ölçmede, sıcaklık-zaman indikatörleri kullanılmaktadır. Bunlara örnek olarak alkalin fosfotaz, lipaz, laktoperoksidaz gibi enzimler; laktoferrin, serum albumin ve immunoglobulin gibi asitte çözünebilen peyniraltı suyu proteinleri; laktuloz, HMF ve 
furosin gibi Maillard reaksiyon bileşenleri verilebilir (Martin ve ark., 2005; Mayer ve ark., 2010; Lorenzan ve ark., 2011). Bu indikatörlerden peyniraltı suyu proteinleri ve enzimler düşük sıcaklık uygulaması sonucu oluşan Tip 1 reaksiyonlarının; Maillard reaksiyonu bileşenleri ise yüksek sıcaklık uygulaması sonucu oluşan Tip 2 $\begin{array}{ll}\text { reaksiyonlarının } & \text { göstergesidir. } \\ \text { indikatörlerden } & \text { bazılarının }\end{array}$ bulunabilecek miktarları Uluslararası Sütçülük Federasyonu tarafından tanımlanmıştır. Bu tanımlama Çizelge 1.'de özetlenmiştir (Claeys ve ark., 2002; Claeys ve ark., 2004; Clawin-Rädecker ve ark., 2000; Mayer ve ark., 2010).

Çizelge 1. Sütte izin verilen furosin ve $\beta$ - Laktoglobulin miktarları

Table 1. The limits of furosine ve 6 -Lactoglobulin in milk

\begin{tabular}{|c|c|c|}
\hline $\begin{array}{l}\text { Süt Çeşitleri } \\
\text { Milk Types }\end{array}$ & $\begin{array}{l}\text { Furosin ( } \mathrm{mg} \mathrm{L}^{-1} \text { süt) (en az) } \\
\text { Furosine (mg L }{ }^{-1} \text { milk) (min) }\end{array}$ & $\begin{array}{l}\text { B-Laktoglobulin (mg } 100 \mathrm{~g}^{-1} \text { protein) (en çok) } \\
\text { 6-Lactoglobulin (mg } 100 \mathrm{~g}^{-1} \text { protein)(max) }\end{array}$ \\
\hline $\begin{array}{l}\text { Pastörize süt } \\
\text { Pasteurized milk }\end{array}$ & 8 & 2600 \\
\hline $\begin{array}{l}\text { HTST pastörize süt } \\
\text { HTST Pasteurized milk }\end{array}$ & 20 & 2000 \\
\hline $\begin{array}{l}\text { UHT süt } \\
\text { UHT milk }\end{array}$ & 250 & 50 \\
\hline
\end{tabular}

ESL sütün tanımlanmasında olduğu gibi bu tip bileşen limitlerinin belirlenmesinde de herhangi bir netlik yoktur; ancak ESL sütte $\beta$ Lactoglobulin > $1800 \mathrm{mg} / \mathrm{L}$; furosin $<12 \mathrm{mg} /$ $100 \mathrm{~g}$ protein ve laktuloz $<30 \mathrm{mg} / \mathrm{L}$ olması gerektiği konusunda öneriler bulunmaktadır (Dyck, 2004; Gallmann ve ark., 2001; Mayer ve ark., 2010). Bu çalışmada amaç, içme sütü üretiminde $\quad E S L$ teknolojisinin uygulanabilirliğini incelemek ve bu teknolojiyi diğer ısıl işlemlere göre ve kendi içinde değerlendirmektir.

\section{ESL Süt Üretim Teknolojisi}

\section{MF-KSYS uygulaması}

Bu uygulama, ESL süt üretiminde en çok kullanılan yöntemdir. Mikrofiltrasyon; gözenek çapı 0.2-2 $\mu \mathrm{m}$ arasında değişen genellikle seramik membranlar yardımıyla akışkanı oluşturan bileşenlerin basınç farkından yararlanarak partikül büyüklüğüne göre ayrıştırılması işlemidir. Süt bileşenlerinden yağ globüllerinin partikül çapının, sütten MF ile ayrıştırılmak istenilen mikroorganizma ve sporların partikül boyutuna yakın olması sebebiyle MF uygulamasında kullanılacak sütün yağsız süt olması gereklidir. Bu sebeple MF-KSYS uygulamasında Şekil 1'de de görüldüğü gibi ilk önce süt separatörde krema ve yağsız süt olmak üzere 2 kısma ayrılmaktadır. Ardından yağsız süt $M F$ ile içerisinde bakterilerin, sporlarının ve kazeinin bulunduğu 'Retantat' veya 'Konsantrat' ve içerisinde PAS proteinleri ile laktoz ve minerallerin bulunduğu 'Permeat' veya 'Filtrat' adı verilen 2 kısma ayrılmaktadır. Retantat; molekül ağırlığı 200 kDa'dan fazla olan ve MF membranlarından geçemeyen kısımdır. Permeat ise membrandan geçebilen kısımdır. Retantat ve süt tipine (Tam yağlı/Yağsız) göre ilave edilecek krema $120-130^{\circ} \mathrm{C}$ arasında 4 - 6 sn'lik bir sıcaklık uygulamasına tabi tutulmaktadır (Rosenberg, 1995). Daha sonra bu karışıma MF ile ayrılan permeat ilave edilmekte ve $55^{\circ} \mathrm{C}$ 'de homojenize edilmektedir. $\quad 72^{\circ} \mathrm{C}^{\prime}$ de $\quad 15$ sn'lik pastörizasyonun ardından hijyenik koşullarda partiküler hava ile temizlenmiş paketleme sistemlerinde paketlenmektedir (Henyon, 1999). 
MF uygulaması endüstriyel anlamda ilk defa 1980'lerde peynir üretiminde kullanılmıştır. Sert ve yarı sert peynir üretiminde teknolojik sorunlara sebep olan Clostridium tyrobutricum sporlarını uzaklaştırmada bu teknolojiden yararlanılmıştır (Puhan, 2000).

MF ile sütteki toplam bakteri içeriğinde 4 log düzeyinde azalış gözlemlenirken, spor formunda 2-3 log düzeyinde azalış gözlemlenmektedir. Her ne kadar MF, mikrobiyolojik açıdan sütte önemli düzeyde bir azalma sağlasa da depolama süresi boyunca sütte patojenik mikroorganizmaların gelişmesi önemli bir risk oluşturmaktadır. Bu sebeple MF ancak bir ısıl işlemle birlikte kullanıldığında sütün raf ömrünün uzatılmasında fayda sağlamaktadır (Fernández García ve Riera Rodríguez, 2014).

Schmidt ve ark., (2012) farklı sıcaklıklarda depolanan $\left(4,8\right.$ ve $\left.10^{\circ} \mathrm{C}\right)$ depolanan ESL sütte Gram(-) bakterilerin belirgin bir şekilde geliştiği ve bununla beraber patojen karakterde olan Paenibacillus cinsi ile Bacillus cereus türü bakterilerin spor formlarına da rastlandığı belirtmektedir. Duyusal olarak değerlendirildiğinde ESL sütün pastörize süt ile birbirine yakın tada sahip olduğu ancak UHT sütten ise bariz bir şekilde farklı tada sahip olduğu belirtilmektedir. Ayrıca depolama süresi uzadıkça ESL süt ile pastörize sütün yakın tada sahip olduğu bildirilmektedir (Grabowski ve ark., 2012).

Lorenzen ve ark., (2011) yapmış oldukları çalışmada besinsel içeriği (yă̆, protein ve kuru madde içeriği) açısından mikrofiltrasyonla üretilen ESL sütün, pastörize ve UHT süte göre önemli derecede farklılık göstermediğini ve birbirine yakın değerlere sahip olduğunu tespit etmişlerdir. Ancak vitamin içeriği bakımından kıyaslandığında farklı yöntemlerle üretilen bu sütlerin önemli düzeyde farklılık gösterdiği belirtilmektedir. Aynı çalışmada yapılan duyusal testlere göre; tatlıık yönünden UHT süt ile pastörize sütün birbirine yakın değerlere sahip olduğu ve MF-KSYS sütten daha yüksek değerler aldığı belirtilmektedir. Ayrıca MF-KSYS sütte pişmiş ve yabancı tat diğerlerine göre daha az oranda tespit edilmiştir. Schmidt ve ark., (2012) çalışma sonuçlarından farklı olarak bu çalışmada depolama boyunca sütlerin duyusal özelliklerinde dikkate değer bir farklılık gözlemlenmediği belirtilmektedir.

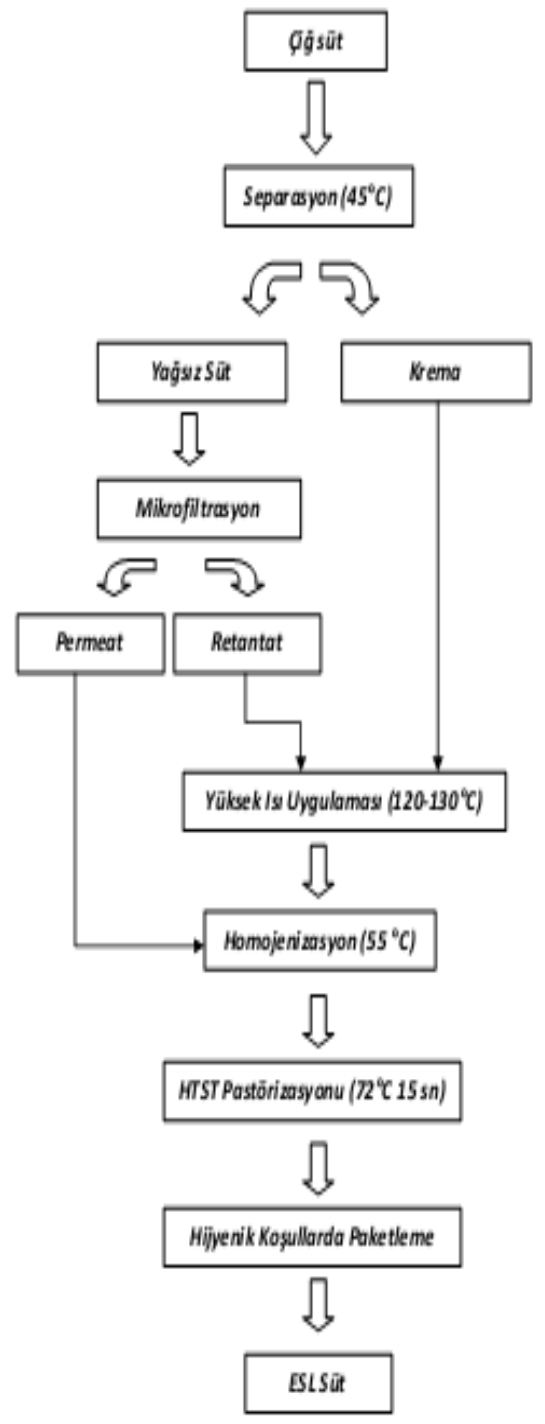

Şekil 1. MF-KSYS uygulaması ile ESL süt üretim aşamaları

Figure 1. ESL milk production by MF-HTST treatment 
Baktofügasyon - KSYS Uygulaması

Baktofügasyon, yüksek hızda santrifüj kuvveti yardımıyla $55-60^{\circ} \mathrm{C}$ sıcaklıkta sütteki bakterilerin önemli bir kısmının uzaklaştırılması işlemidir. Bakteri hücrelerinin özellikle de bunların spor formlarının yoğunluğu, sütün yoğunluğundan daha fazla olduğu için (Yağsız süt: $1.036 \mathrm{~g} \mathrm{~cm}^{-}$ 3; bakteriler: $1.07-1.13 \mathrm{~g} \mathrm{~cm}^{-3}$ ) bu tip hücreler sütten merkezi bir kuvvetle kolaylıkla uzaklaştırılabilmektedir. Böylece süt bakteri hücreleri ve sporlarınca zengin ve fakir olmak üzere iki kısma ayrılmaktadır. Bakteri hücreleri ve sporlarınca zengin olan kısım uzaklaştırıldıktan sonra geriye kalan kısım $55^{\circ} \mathrm{C}^{\prime}$ de homojenizasyona tabi tutulmaktadır. Son olarak $72^{\circ} \mathrm{C}^{\prime}$ de 15 sn'lik bir KSYS uygulamasının ardından son derece hijyenik koşullarda paketlenmektedir (Faccia ve ark., 2013).

Süte bir kez baktofügasyon işlemi uygulandığında sütte $\% 60-85$ oranında bakteriyel azalma gözlenirken; iki kez uygulandığında ise \%95 oranında bir azalma sağlandığı bildirilmektedir (De Noni ve ark., 2007; Faccia ve ark., 2013). Bu uygulama sütün raf ömrünü ekstra 2-3 gün daha uzatabilirken, uygulanacak pastörizasyon sıcaklığının düşmesine bağlı olarak sütün duyusal kalitesinin artmasına katkıda bulunmaktadır (Guizani, 2007). Bu sebeple, baktofügasyon diğer ESL süt üretim metotlarına göre daha az kullanılmaktadır. Baktofügasyonla ayrılan ve sisteme giren sütün \%3'ünü oluşturan baktofügat 130$140^{\circ} \mathrm{C}^{\prime}$ de 3-4 sn isıl işleme tabi tutularak steril edilmektedir (Anonim, 2016). Steril edilen baktofügat, tekrar süt üretim hattına ilave edilebilmektedir. Böylece baktofügat ayrılmasından kaynaklanabilecek protein içeriğinde, kuru madde içeriğinde ve toplam hacimde oluşabilecek azalmalar önlenmektedir (Scott ve ark., 1988).
Bu uygulama ile üretilen süt, UHT içme sütü gibi tamamen mikroorganizmalarından arındırılmış değildir. İçerisinde ısıya dirençli bazı mikroorganizmaları ve bazı bakterilerin spor formlarını da barındırabilmektedir. Bu sebeple baktofügasyonla üretilen sütler, pastörize sütler gibi bu bakterilerin gelişerek sütte bozulmaya sebep olabileceği sıcaklık derecesinin $\left(7^{\circ} \mathrm{C}\right)$ altında muhafaza edilmelidir (Walstra ve ark., 1999).

Baktofügasyon endüstriyel anlamda çoğunlukla peynir üretiminde ve süt tozu üretiminde kullanılmaktadır (White ve ark., 2008; Papachristou ve ark., 2006). Pastörizasyonla üretilen sütlerde; özellikle Clostridium tyrobutyricum gibi basil formda, ısıya dirençli mikroorganizmaların spor formları bulunabilmektedir ve uygun şartlar sağlandığında bu sporlar gelişerek vejatatif hücrelere dönüşebilmektedir. Bu mikroorganizmaların preteolitik ve lipolitik aktiviteleri sonucunda bu tip sütlerden elde edilen peynirlerde teknolojik ve hijyenik sorunlar oluşmaktadır. Bu tip sorunları önlemek için ise ön işlem olarak süte baktofügasyon uygulanmakta ve bu mikroorganizma sporlarının uzaklaşması sağlanmaktadır (Ayar ve Özdemir, 2002; Kolhe ve ark., 2009). İçme sütünden Bacillus cereus gibi mikroorganizmaların spor formlarının uzaklaştırılmasında peynir üretiminde olduğu gibi bu uygulamadan yararlanılmaktadır (Walstra ve ark., 1999).

\section{VEA-KSYS UygulamasI}

Vurgulu elektriksel alan, ısıl işlemin etkisini azaltarak sütün raf ömrünü uzatmaya dayalı bir yöntemdir. Bu işlemde, süt önce $72^{\circ} \mathrm{C}^{\prime}$ de 15 sn'lik bir KSYS işlemine tabi tutularak pastörize edilmektedir. Daha sonra pastörize süt $2.3 \mu$ s genişliğindeki vurgular ile $35 \mathrm{kV} / \mathrm{cm}^{\prime}$ lik elektriksel alandan geçirilmektedir. Bu uygulamada, 2 elektrot 
arasında oluşan elektriksel alanın mikroorganizmalar üzerindeki inaktive edici etkisinden yararlanılmaktadır. Bu yöntemle sütün raf ömrü 44 güne kadar uzatılabilmektedir (Sepulveda ve ark., 2005). $\mathrm{Bu}$ uygulamanın toplam enerji tüketimi mikroorganizma çeşidine ve gıdanın mikrobiyal yüküne bağlı olarak litre başına 107-201 kJ iken; KSYS uygulamasının toplam enerji tüketiminin litre başına 300 kJ olduğu belirtilmektedir (Fernández-Molina ve ark., 2005). Ayrica VEA uygulaması ISI uygulamalarıyla birlikte kullanıldığında enerji sarfiyatının, VEA uygulamasının tek başına uygulandığı duruma kıyasla daha az olduğu belirtilmektedir (Rowan ve ark., 2000).

VEA uygulaması ilk kez 1900'lerde tasarlanmış ve gıdalarda ilk uygulaması süt üzerinde denenmiştir. Beattie and Lewis (1925), Fetterman (1928), Getchell (1935) gibi birçok araştırmacı farklı zamanlarda farklı voltajlarda elektrik akımı kullanarak sütteki mikroorganizmaları uzaklaştırmayı denemişlerdir. VEA uygulaması, elektriksel alan gücü ve elektrik atılımı sayısına bağlı olarak mikroorganizmalar üzerinde etkili olmaktadır (Bendicho ve ark., 2002). Elektriksel alana maruz bırakılan mikroorganizmaların hücre membranlarının geçirgenliği artmaktadır. Bunun sonucu olarak Şekil 2'de de görüldüğü gibi hücre su alarak şişmekte ve parçalanmaktadır (VegaMercado ve ark., 1997).

VEA uygulamasının sadece vejatatif hücreler üzerinde etkisinin bulunduğu, spor formları üzerinde ise herhangi bir etkisinin olmadığı (Grahl ve Märkl, 1996), Gram (-) bakterilerin Gram (+) bakterilere göre daha duyarlı olduğu ve mikroorganizmaların logaritmik artış evresinde VEA uygulamasına daha duyarlı oldukları bildirilmiştir (Wouters ve ark., 1999; Rodrigo ve ark., 2001; Picart ve ark., 2002).

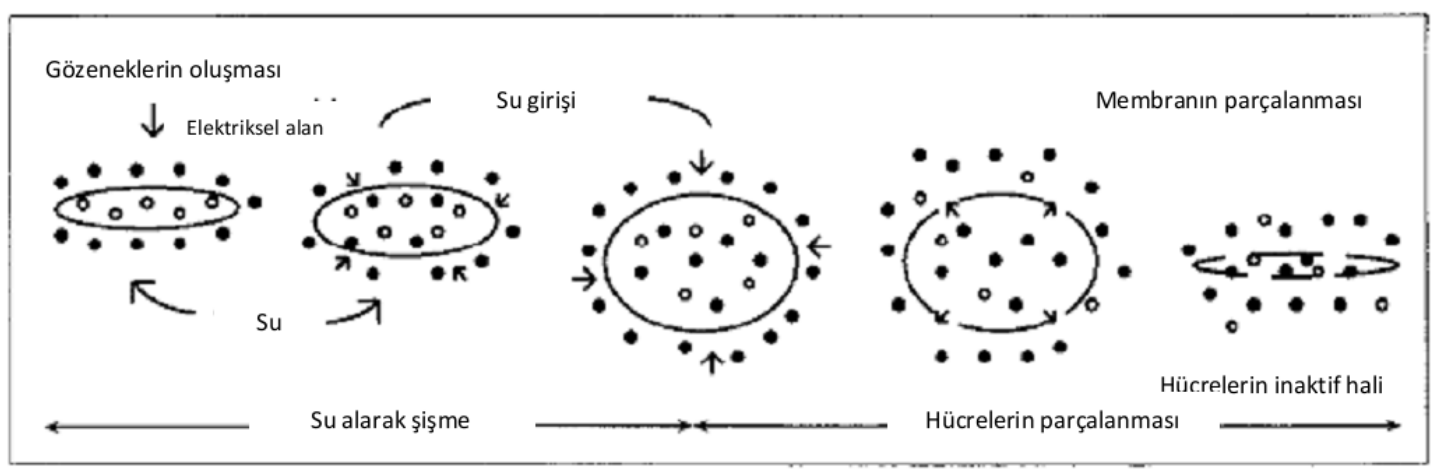

Şekil 2. VEA ile hücre inaktivasyonu

Figure 2. Cell inactivation by pulsed electric field

Yu ve ark. (2009), VEA uygulamasının patojen mikroorganizmalarda 5 log düzeyine kadar azalma sağladığı, bu uygulama ısıl işleme oranla protein, vitamin gibi sıcaklığa duyarlı bileşenlerinde daha az zarara neden olduğu tespit etmişlerdir. Bendicho ve ark. (2012), ise tiamin, riboflavin, tokoferol gibi vitaminlerin VEA uygulamasından etkilenmediğini, askorbik asidin ise önemli düzeyde etkilendiğini bildirmiştir. Qin ve ark. (1995), VEA - pastörizasyon uygulaması ile üretilen sütler ile yalnızca pastörizasyonla üretilen sütler arasında duyusal açıdan önemli bir fark olmadığını belirtmektedirler.

Sepulveda-Ahumada ve ark. (2000), VEA uygulaması ile üretilen sütten, farklı sıcaklık 
dereceleri ve süre normları uygulanarak üretilen pastörize sütten $\left(63^{\circ} \mathrm{C}-30 \mathrm{dk} / 72^{\circ} \mathrm{C}\right.$ $15 \mathrm{dk}$ ) ve çiğ sütten elde edilen peynirlerin tekstürel özelliklerini incelemişlerdir. VEA uygulaması ve pastörizasyonla üretilen sütten elde edilen peynirlerin; sertlik, yapışkanlık, esneklik özellikleri açısından birbirlerine yakın olduğunu, ancak VEA uygulaması ile üretilen sütten elde edilen peynirlerin çiğ sütten üretilen peynirlerden belirtilen tekstürel özellikler açısından daha yüksek değerlere sahip olduğu belirtilmektedir.

\section{YHB Uygulaması}

Yüksek hidrostatik basınç uygulaması, gıdanın genellikle oda sıcaklığında $2-30 \mathrm{dk}$ süre ile 300-600 MPa olarak değişen basınca maruz bırakılmasıdır (Datta ve Deeth, 1999). Böylece gıdanın mikrobiyal yükü azaltılarak raf ömrü uzatılmaktadır. Isıl işlemlere göre bu yöntemin gıdada yapısal bozulma oluşturma etkisi ile gıdanın bileşenleri üzerine olumsuz etkisinin düşük olduğu, ayrıca bu işlemin kovalent olmayan bağlar içeren büyük moleküller (proteinler, polisakkaritler vb.) üzerinde daha çok etki oluşturduğu bildirilmektedir. Daha çok kovalent bağlar içeren vitaminler, renk ve aroma bileşenleri gibi küçük moleküllerin ise YHB uygulamasından daha az etkilendiği belirtilmektedir (San Martín ve ark., 2002).

Yüksek basınç uygulamasının mikroorganizmaların vejatatif formları üzerindeki etkisi ilk önce hücre membranında görülmektedir. Yüksek hidrostatik basınç, hücre membranında bulunan protein gibi makromolekülleri etkilemesi sonucu hücre membranı zarar görmektedir. Ardından membranda bulunan ATPaz enziminin inaktif hale geçmesiyle hücre canlılı̆̆ için son derece önemli olan nükleik asit ve ribozom sentezi durmaktadır.
Sonuçta bu zincirleme olaylar bakteri hücresinin canlılığını kaybetmesine sebep olmaktadır. Genel olarak yüksek hidostatik basınca Gram (-) bakteriler Gram (+) bakterilere göre daha duyarlı, çubuk şeklindeki bakteriler koklara göre daha duyarlı olduğu savunulmaktadır. Gram (+) ve (-) bakteriler arasındaki bu duyarlıık farkının hücre duvarını güçlendiren teikoik asitten kaynaklanabileceği düşünülmektedir. Ayrıca gelişiminin log fazında olan bakterilerin yüksek hidrostatik basınca daha duyarlı olduğu saptanmıştır. Bunların dışında maya ve küflerin duyarlılığı ise bakterilere göre daha yüksektir (Considine ve ark., 2008). Bakterilerin spor formlarının YHB'ye dayanıklı oldukları ve $1200 \mathrm{MPa}$ basınca kadar canlılıklarını sürdürebildikleri tespit edilmiştir. Ayrıca düşük basınç uygulamalarının (60 - $100 \mathrm{MPa}$ ) sporların gelişimine pozitif yönde katkıda bulunduğu savunulmaktadır (San Martín ve ark., 2016). Sporların basınca en dayanıklı mikroorganizma olmasının sebebi yapılarındaki kalsiyumca zengin dipikolinik asitten kaynaklandığı düşünülmektedir. Bu asit hücre çoğalmasının bir göstergesi olup basıncın etkisiyle hücreden uzaklaşarak hücreyi korur (Smelt, 1998).

$\mathrm{Bu}$ prosesin en büyük avantajı; ürünün yapısından ve zamandan bağımsız olarak homojen bir şekilde uygulanabilirliğidir. Bu yüzden gıda endüstrisinde hem katı hem de sıvı gıdalar için geniş kullanım alanı oluşturmaktadır. Genellikle bu uygulama sınırlandırılmış bir alanda gıda üzerine basıncın izostatik olarak bir sıvı yardımıyla iletilmesi şeklinde gerçekleştirilmektedir. Basıncın iletilmesini sağlayan sıvı ortam olarak genellikle su kullanılmakta ve bu sıvı gidaya temas etmemektedir. Bir YHB prosesi basınç odası, basınçlandırma sistemi, sıcaklık kontrol sistemi, ürün işleme cihazı olmak 
üzere 4 kısımdan oluşur (San Martín ve ark., 2002).

$\mathrm{Bu}$ uygulamanın temelinde 2 farklı prensip vardır. Birincisi etkiye tepki mekanizmasında dayanan Le Chatelier prensibidir. YHB sisteminde dışarıdan sisteme verilen etki basınçtır, sistemin bu etkiyi azaltıcı yöndeki tepkisi ise hacmin azaltarak yoğunluğu arttırmaktır. Böylece hücrelerin kimyasal dengesi $(\mathrm{pH}$ düşüşü, protein denatürasyonu gibi) değişerek zarar görmektedir. Diğeri ise basıncın aniden ve homojen olarak dağılması anlamına gelen izostatik etkidir (Chawla ve ark., 2009). Ayrıca bu uygulama adyabatik bir süreci de kapsar. Gıdaya basıncın uygulanmasıyla birlikte gıdada görülen sıcaklık artışı basıncın kaldırılmasıyla birlikte elimine edilir. Kısaca gıda ile ortam arasında herhangi bir sıcaklık alışverişi gerçekleşmez (Considine ve ark., 2008).

YHB uygulaması, termal bir proses olan pastörizasyon teknolojisiyle karşılaştırıldığında; inek ve keçi sütündeki çözünür kalsiyum, fosfor ve magnezyum oranını bu uygulamanın (400 MPa, $10 \mathrm{dk}$ ) pastörizasyona $\left(85^{\circ} \mathrm{C}, 30 \mathrm{dk}\right)$ göre daha çok arttırdığı tespit edilmiştir. YHB uygulaması ISI uygulamasıyla birlikte kullanıldığında (300 $\mathrm{MPa}, 75{ }^{\circ} \mathrm{C}, 30 \mathrm{dk}$ ) ise bu mineral madde oranlarının yalnızca ısı uygulamasıyla üretilen sütlerden yüksek, yalnızca YHB uygulamasıyla üretilen sütlerden ise düşük olduğu tespit edilmiştir (De Le Fuente ve ark., 1999).

Amador-Espejo ve ark. (2014) farklı sıcaklık ve basınç uygulamaları üretilen süt örnekleriyle ile UHT ve çiğ süt örneklerini renk özellikleri bakımından kıyaslamışlar ve $L^{*}$ değerinin çiğ sütte en düşük olduğunu tespit etmişlerdir. UHT ve YHB kombinasyonuyla üretilen sütlerin ise $L^{*}$ (Açıklık-Koyuluk Ekseni Değeri) değerlerinin birbirine yakın olduğu tespit edilmiştir. Renk parametrelerinden a* (Kırmızı-Yesil Ekseni Değeri) değerinin, çiğ süt ve UHT sütte birbirine yakın olduğu, YHB-ısı uygulamasıyla üretilen sütlerin $a^{*}$ değerinin ise diğer süt örneklerinden daha yüksek olduğu tespit edilmiştir. Diğer bir renk parametresi olan $b^{*}$ (Sarı-Mavi Ekseni Değeri) değerinin ise basınç uygulamasıyla azaldığı belirtilmektedir. Duyusal özellikleri açısından değerlendirildiğinde ise UHT süt örnekleri ile YHB-ıSı uygulaması ile üretilen süt örnekleri istatistikî açıdan arasında önemli bir fark gözlemlenmemiştir $(P<0.05)$, ancak YHB-ISI uygulaması ile üretilen süt örneklerinde pişmiş ve tuzlu tadın daha az algılandığı belirtilmektedir.

\section{Sonuçlar}

Beslenmede protein, karbonhidrat, yağ, mineral maddeler ve vitaminler gibi pek çok önemli fonksiyona sahip bileşenleri içeren sütün sağımından tüketiciye ulaşıncaya kadar geçen süreçte besinsel özelliklerinin korunması, hijyenik koşullarda işlenmesi ve muhafazası önemli bir husustur. Tüm bu şartları sağlamak için günümüzde ısıl işlem kaçınılmaz bir uygulamadır. Ancak, bu uygulamanın proses parametrelerine bağlı olarak düşük düzeyde de olsa sütün duyusal ve besinsel kalitesi açısından olumsuz sonuçlar doğurabileceği yönünde bulgular mevcuttur. Bu sebeple daha iyi bir ürün elde etme amacıyla yeni tekniklerin geliştirilmesi hem gıda sanayi hem de tüketiciler açısından önemlidir. Her ne kadar uygulama çeşidine bağlı olarak kendi içerisinde üretim kapasitesi, sürekliliği, kurulum maliyeti, pazar payı gibi dezavantajları bulunsa da ESL süt üretim teknolojisi gelecek vadeden bir tekniktir. Duyusal ve besinsel özellikler açısından daha iyi bir ürün oluşturabilme kapasitesine sahip olan bu tekniğin eksiklikleri giderildiğinde, diğer teknolojilerle 
rekabet edebilecek düzeye gelecek ve endüstriyel anlamda kullanımı yaygınlaşacaktır. $\mathrm{Bu}$ savı geçmişten günümüze yeni ürün geliştirme adına yapılan çalışmalar da destekler niteliktedir. Tüm bu çalışmaların asıl amacı, tüketiciye taze ve dayanıklı bir ürün sunabilmektir. Bu noktada ülkemizde süt ve süt ürünleri sektörünün geliştirilmesi yönünde atılan adımları desteklemek, bunların uygulanabilirliğini arttırmak için çözümler üretmek ve bu konularda üretici ve tüketicileri bilgilendirmek gelecek için faydalı bir yatırım olacaktır.

\section{Kaynaklar}

Amador-Espejo, G.G., Suàrez-Berencia, A., Juan, B., Bárcenas, M.E., Trujillo, A.J., 2014. Effect of moderate inlet temperatures in ultra-high-pressure homogenization treatments on physicochemical and sensory characteristics of milk. Journal of dairy science, 97 (2): 659-671.

Anonim, 2016. http://ecoursesonline.iasri.res.in/mod/pag e/view.php?id=6140 Erişim Tarihi: 22.08.2016.

Ayar, A., Özdemir, M., 2002. Konya'da Satılan Beyaz Peynirlerin Nitrat ve Nitrit İçerikleri. Selçuk Tarım Bilimleri Dergisi, 16 (29): 8487.

Beattie, J.M., Lewis, F.C., 1925. The electric current (apart from the heat generated). A bacteriological agent in the sterilization of milk and other fluids. The Journal of Hygiene, 24 (2): 123-137.

Bendicho, S., Barbosa-Cánovas, G.V., Martín, O., 2002. Milk processing by high intensity pulsed electric fields. Trends in Food Science \& Technology, 13 (6): 195-204.

Chawla, R., Patil, G.R., Singh, A.K., 2011. High hydrostatic pressure technology in dairy processing: a review. J Food Sci Technol, 48 (3): $260-268$.

Claeys, W.L., Van Loey, A.M., Hendrickx, M.E., 2002. Intrinsic time temperature integrators for heat treatment of milk. Trends Food Sci. Technol. 13 (9): 293-311.

Claeys, W.L., Smout, C., Van Loey, A.M., Hendrickx, M.E., 2004. From time integrator kinetics to time temperature integrator tolerance levels: heat-treated milk. Biotechnol. Prog. 20 (1): $1-12$.

Clawin-Rädecker, I., Kiesner, C., Martin, D., 2000. Furosine and ribonucleosides: indicators for the heat treatment of milk. Milchwissenschaft, 55 (12): 679- 682.

Considine, K.M., Kelly, A.L., Fitzgerald, G.F., Hill, C., Sleator, R.D., 2008. High - pressure processing - efects on microbial food safety and food quality. FEMS Microbiology Letters, 281 (1): 1-9.

Datta, N., Deeth, H.C., 1999. High pressure processing of milk and dairy products. The Australian Journal of Dairy Technology, 54 (1): 41.

De Le Fuente, M.A., Olano, A., Casal, V., Juárez, M., 1999. Effects of high pressure and heat treatment on the mineral balance of goats' milk, Journal of Dairy Research, 66 (1): 65-72.

De Noni, I., Pellegrino, L., Cattaneo, S., Resmini, P., 2007. HPLC of proteose peptones for evaluating ageing of packaged pasteurized milk. International Dairy Journal, 17 (1): 12-19.

Dyck B., 2004. Neue Marktchancen durch ESLTechnologie, Dt. Molk. Ztg. (dmz), 20: 2225.

Faccia, M., Mastromatteo, M., Conte, A., Alessandro Del Nobile, M., 2013. Influence of the Milk Bactofugation and Natural Whey Culture on the Microbiological and Physico-Chemical Characteristics of Mozzarella Cheese. Journal of Food Processing \& Technology, 4 (4): 1-7.

Fernández-Molina J.J, Fernández-Gutiérrez S.A, Altunakar B., Bermúdez-Aguirre D., Swanson G.G, Barbosa-Cánovas G.V., 2005. The combined effect of pulsed electric fields and conventional heating on the microbial quality and shelf life of skim milk. J Food Process Preserv, 29: 390-406.

Fetterman, J.C., 1928. The electrical conductivity method of processing milk. Agricultural Engineering, 9 (4): 107-108.

Gallmann, P., Eberhard, P., Sieber, R., 2001. Vorund Nachteile der ESL (Extended Shelf Life)-Milch. Agrarforschung, 8: 112- 117.

García, L.F., Rodríguez, F.R., 2014. Combination of microfiltration and heat treatment for ESL milk production: Impact on shelf life. Journal of Food Engineering, 128: 1-9. 
Getchell, B.E., 1935. Electric pasteurization of milk. Agricultural Engineering, 16 (10): 408-410.

Grabowski, N.T., Ahlfeld, B., Brix, A., Hagemann, A., von Münchhausen, C., Klein, G., 2013. Similarities and differences among fluid milk products: traditionally produced, extended shelf life and ultrahightemperature processed. Food Science and Technology International, 19 (3): 235-241.

Grahl, T., Märkl, H., 1996. Killing of microorganisms by pulsed electric fields. Appl Microbiol Biotechnol, 45 (1-2): 148157.

Guizani, N., 2007. Postharvest Handling of Milk. "Alınmıştır: Handbook of food preservation. (Ed) Rahman, M.S., CRC press, Boca Raton, 203-211pp.

Gündoğdu, E., Yıldız H., Çakmakçı, S., 2012. Süt Bileşenleri Üzerine Isıl İşlemin Etkileri ve Besin Değeri Konusunda Değerlendirmeler. Tarım Bilimleri Araştırma Dergisi, 5 (1): 162-165.

Henyon, D.K., 1999. Extended shelf-life milks in North America: a perspective. International journal of dairy technology, 52 (3): 95-101.

Hoffmann, W., Kiesner, C., Clawin-Rädecker, I., Martin, D., Einhoff, K., Lorenzen, P. C., Meisel, H., Hammer, P., Suhren, G., Teufel, P., 2006. Processing of extended shelf life milk using microfiltration. International journal of dairy technology, 59 (4): 229235.

Kalkan, S., Halkman, K., 2006. Bacillus cereus ve İçme Sütünde Oluşturduğu Sorunlar. Orlab On-Line Mikrobiyoloji Dergisi, 4 (1): 1-11.

Kolhe, A.S., Ingale, S.R., Bhole, R.V., 2009. Effluent of dairy technology. Shodh, Samiksha aur Mulyankan Int Res J, 2 (5): 459-461.

Lorenzen, P.C., Clawin-Rädecker, I., Einhoff, K., Hammer, P., Hartmann, R., Hoffmann, W., Martin, D., Molkentin, J.,Walte, H.G., Devrese, M., 2011. A survey of the quality of extended shelf life (ESL) milk in relation to HTST and UHT milk. International journal of dairy technology, 64 (2): 166178.

Martin, D., Linxweiler, W., Tanzer, D., Vormbrock, R., Olt, R., Kiesner, C., Meisel, H., 2005. Use of the Reflectoquant ${ }^{\circledR}$ rapid tests for determination of thermal inactivation of the indigenous milk enzymes lipase, alkaline phosphatase and lactoperoxidase.
Deutsche Lebensmittel-Rundschau, 101 (7): 281- 286.

Mayer, H.K., Raba, B., Meier, J., Schmid, A., 2010. RP-HPLC analysis of furosine and acidsoluble $\beta$-lactoglobulin to assess the heat load of extended shelf life milk samples in Austria. Dairy science \& technology, 90 (4): 413-428.

Papachristou, C., Badeka, A., Chouliara, I., Kondyli, E., Kourtis, L., Kontominas, M.G., 2006. Evaluation of polyethylene terephthalate as a packaging material for premium quality whole pasteurized milk in Greece. European Food Research and Technology, 224 (2): 237-247.

Picart, L., Dumay, E., Claude Cheftel, J., 2002. Inactivation of Listeria innocua in dairy fluids by pulsed electric fields: influence of electric parameters and food composition. Innovative Food Science and Emerging Technologies, 3 (4): 357-369.

Puhan, Z., 2000. Dairy technology on the turn of the millennium. Zbornik Biotehniske Fakultete Univerze v Ljubljani. Kmetijska Zootehnika, 76 (2): 31-40.

Qin, B.L., Pothakamury, U.R., Vega, H., Martin, O., Barbosa-Canovas, G.V., Swanson, G., Mermelstein, N., $1995 . \quad$ Food pasteurization using high-intensity pulsed electric fields. Food Technology, 49 (12): 55-60.

Raynal-Ljutovac, K., Park, Y.W., Gaucheron, F., Bouhallab, S., 2007. Heat stability and enzymatic modifications of goat and sheep milk. Small Ruminant Research, 68 (1): 207-220.

Rodrigo, D., Martinez, A., Harte, F., BarbosaCanovas, G.V., Rodrigo, M., 2001. Study of inactivation of Lactobacillus plan-tarum in orange-carrot juice by means of pulsed electric fields: comparison of inactivation kinetics models. Journal of Food Protection, 64 (2): 259-263.

Rosenberg, M., 1995. Current and future applications for membrane processes in the dairy industry. Trends in Food Science \& Technology, 6 (1): 12-19.

Rowan N.J., MacGregor S J., Anderson J.G., Fouracre R.A., Farish O., 2000. Pulsed electric field inactivation of diarrhoeagenic Bacillus cereus through irreversible electroporation. Lett Appl Microbiol, 31: 110-114.

Rysstad, G., Kolstad, J., 2006. Extended Shelf Life Milk-Advances in Technology. 
International Journal of Dairy Technology, 59 (2): 85-96.

San Martín , M.F., Barbosa-Cánovas, G.V., Swanson, B.G., 2002. Food Processing by High Hydrostatic Pressure. Critical Reviews in Food Science and Nutrition, 42 (6): 627645.

Schmidt, V.S., Kaufmann, V., Kulozik, U., Scherer, S., Wenning, M., 2012. Microbial biodiversity, quality and shelf life of microfiltered and pasteurized extended shelf life (ESL) milk from Germany, Austria and Switzerland. International journal of food microbiology, 154 (1): 1-9.

Scott, R., Robinson, R.K., Wilbey, R.A., 1998. Cheesemaking Practice (3rd edition). Kluwer Academic /Plenum Publishers, New York, 132-133pp.

Sepulveda-Ahumada, D.R., Ortega-Rivas, E., Barbosa-Cánovas, G.V., 2000. Quality aspects of cheddar cheese obtained with milk pasteurized by pulsed electric fields. Food and bioproducts processing, 78 (2): 65-71.

Sepulveda, D.R., Góngora-Nieto, M.M., Guerrero, J.A., Barbosa-Cánovas G.V., 2005. Production of extended-shelf life milk by processing pasteurized milk with pulsed electric fields. Journal of Food Engineering, 67 (1): 81-86.

Smelt, J.P.P.M., 1998. Recent advances in the microbiology of high pressure processing. Trends in Food Science \& Technology, 9 (4): 152-158.

Vega-Mercado, H., Martín-Belloso, O., Qin, B.L., Chang, F.J., Góngora-Nieto, M.M., Barbosa-Cánovas, G.V., Swanson, B.G., 1997. Non-thermal food preservation: Pulsed electric fields. Trends in Food Science \& Technology, 8 (5): 151-157.

Velioğlu Öğünç, A., Yalçın, A. S., 2011. Süt serumu proteinlerinin in vitro koşullardaki antioksidan etkileri. Marmara Eczacılık Dergisi, 15: 18-24.

Walstra, P., Wouters, J.T.M., Geurts, T.J., 1999. Centrifugation. "Alınmıştır: Dairy Science and Technology, CRC Press. Boca Raton, 273-276pp.

White, C.H., Kilara, A., Hui, Y.H., 2008. Manufacturing yogurt and fermented milks. R. C. Chandan (Ed.). "Alınmıştır: Basic Dairy Processing Principles. John Wiley \& Sons, 77-79s.
Wouters, P.C., Dutreux, N., Smelt, J.P.P.M., Lelieveld, H.L.M., 1999. Effects of pulsed electric fields on inactivation kinetics of Listeria innocua. Applied and Environmental Microbiology, 65 (12): 5364-5371.

Yu, L.J., Ngadi, M., Raghavan, G.S.V., 2009. Effect of temperature and pulsed electric field treatment on coagulation properties of milk. Journal of Food Engineering, 95 (1): 115-118 